\title{
The analysis of unit costs of preparing hot water for various sources of heat
}

\author{
Aleksandra Mazur ${ }^{1, *}$, and Daniel Słyś ${ }^{1}$ \\ ${ }^{1}$ Rzeszów University of Technology, Department of Infrastructure and Sustainable Development, al. \\ Powstańców Warszawy 12, 35-959 Rzeszów, Poland
}

\begin{abstract}
The article presents an analysis of energy consumption and the cost of its production by the systems of supply of hot water depending on the applied heat sources and destination of a building. The calculations have taken into account the efficiency of the adopted installation solutions that have a direct impact on energy consumption. The following parameters have been determined: the size of the seasonal demand for hot water, an annual amount of fuel needed to its production and annual operating costs. The calculations have been performed for residential buildings and public buildings, whilst maintaining the same usable space. The aim of the article is to determine the rate of the amount of fuel, needed to heat to the desired temperature, a unit volume of water depending on the type of heat source and destination of a premises. For the adopted variants of installation, the ratio of production costs of unit volume of hot water has been also determined. The indicators of the fuel amount and the cost of hot water pointed out in the article may be one of the criteria for selection of an effective system for the preparation of hot water.
\end{abstract}

\section{Introduction}

Due to rising fuel prices, as well as constantly decreasing natural resources, it is essential to manage our deposits consciously and responsibly, as well as use them effectively. For this reason, the choice of a proper heating system is extremely important, including a system for the preparation of hot water. Today, there is a significant improvement in the thermal insulation of construction bulkheads, resulting in a decrease in energy demand for central heating purposes, and consequently there is an increase in the system for the preparation of hot water. The selection of an appropriate system to supply a building with hot water is not an easy decision and it should be based on a multi-criteria analysis [1]. There are certain attempts that aim at reducing water consumption, as well as reducing the energy required to heat the hot water through recycling greywater and using heat exchangers DWHR $[2,3]$. A reasonable idea seems to be the replacement of inefficient heat sources, with those of higher efficiency; or replacement of the conventional energy carriers with their alternatives. Hence, numerous analyses of installations are being performed, in which renewable energy sources, such as solar collectors, photovoltaic panels, or heat pumps are used [4-7].

* Corresponding author: a.mazur@prz.edu.pl 
The system for the supply of hot water for a building should be matched to the characteristics of water consumption by users. The size of the daily consumption of hot water depends on many factors, such as: sanitary facilities; time of day and year, and the number of users and their habits. Most of these factors are closely connected with the purpose of the building.

The aim of the article is to analyse the energy consumption and the cost of its production in the systems which supply hot water, depending on the applied heat source and the purpose of the building. The scope of the article covers the calculation of the seasonal demand for hot water, the efficiency of the analysed system, the annual amount of fuel necessary for the production of hot water, and the annual operating costs. These values have been calculated with the use of the ArCADia-TERMO 6.5 computer software. The indicator of the amount of fuel needed to heat a unit volume of hot water to the desired temperature, as well as the rate of production costs per unit volume of hot water, depending on the type of heat source and the premise's functions, have been determined.

\section{Installation variants}

For the analysis, six variants of systems which supply a building with hot water have been adopted:

- variant 1: capacitive electric heater,

- variant 2: coal-fired boiler for coal with a storage tank,

- variant 3: biomass boiler with a storage tank,

- variant 4: condensing gas boiler with a storage tank,

- variant 5: oil boiler with a storage tank,

- variant 6: heat pump air / water with a storage tank.

Calculations have been carried out for residential buildings and public buildings such as: an office building, an apartment building, a restaurant, a shopping centre, a hotel, a warehouse, a school, a hospital, and a sports hall.

\section{Analysis of the results}

The legal basis for the calculation is the Ministry of Infrastructure and Development regulation, dated 27 February 2015, on the methodology for determining the energy performance of a building, or part of a building, and energy performance certificates [8], according to which the seasonal demand for hot water is calculated using the following formula [8]:

$$
Q_{w, n d}=V_{W i} \cdot A_{f} \cdot c_{w} \cdot \rho_{w} \cdot\left(\theta_{w}-\theta_{0}\right) \cdot k_{R} \cdot t_{R} / 3600[k W h / \text { year }]
$$

where:

$V_{W i}$ - unitary, daily demand for hot water $\left[\mathrm{dm}^{3} /\left(\mathrm{m}^{2} \cdot\right.\right.$ day $\left.)\right]$,

$A_{f}-$ heated floor space $\left[\mathrm{m}^{2}\right]$,

$c_{w}$ - specific heat of water $[\mathrm{kJ} /(\mathrm{kg} \cdot \mathrm{K})]$,

$\rho_{w}$ - density of water $\left[\mathrm{kg} / \mathrm{dm}^{3}\right]$,

$\theta_{w}$ - calculative temperature of the hot water in the draw-off tap $\left[{ }^{\circ} \mathrm{C}\right]$,

$\theta_{0}-$ calculative water temperature before its heating $\left[{ }^{\circ} \mathrm{C}\right]$,

$k_{R}$ - correction factor, due to an interruption in use of hot water. [-],

$t_{R}$ - number of days in the year [day].

The values of the unitary, daily demand for hot water, and the values for the correction factor have been adopted in accordance with Table 27 of the Ordinance [8]. For all of the analysed buildings, an equal heated area of $1600 \mathrm{~m}^{2}$ has been assumed. The calculative 
temperature of hot water has been assumed at the level of $55^{\circ} \mathrm{C}$, in accordance with [9], and the cold water at the level of $10^{\circ} \mathrm{C}$. A summary, of seasonal calculations for hot water demand $\mathrm{Q}_{\mathrm{w}, \mathrm{nd}}$ are presented in Table 1 .

Table 1. Seasonal demand for hot water $\mathrm{Q}_{\mathrm{w}, \mathrm{nd}}$.

\begin{tabular}{|c|c|c|c|}
\hline Type of building & $\begin{array}{c}\text { Correction factor } \\
\qquad \mathbf{k}_{\mathbf{R}}[-]\end{array}$ & $\begin{array}{c}\text { Unitary, daily demand } \\
\text { for hot water } V_{W i} \\
{\left[\mathbf{d m}^{3} /\left(\mathbf{m}^{\mathbf{2}} \cdot \mathbf{d a y}\right)\right]}\end{array}$ & $\begin{array}{l}\text { Seasonal demand for hot } \\
\text { water } Q_{w, n d}[k W h / y e a r]\end{array}$ \\
\hline Office building & 0.70 & 0.35 & 7494 \\
\hline Apartment building & 0.90 & 1.60 & 44045 \\
\hline Restaurant & 0.80 & 2.50 & 61174 \\
\hline Shopping centre & 0.78 & 0.60 & 14315 \\
\hline Hotel & 0.60 & 3.75 & 68821 \\
\hline Warehouse & 0.70 & 0.10 & 2141 \\
\hline School & 0.55 & 0.80 & 13458 \\
\hline Hospital & 1.00 & 6.50 & 198816 \\
\hline Sports hall & 0.42 & 0.25 & 3173 \\
\hline
\end{tabular}

The efficiencies of the calculation systems used in determining the demand for hot water has been set in the study. The total system efficiency is calculated as the quotient of the following elements: the average annual efficiency of the heat production from energy carrier, the average annual efficiency of heat transfer from the heat source to the draw-off taps, the average annual efficiency of the heat accumulation in the capacitive elements, and the average annual efficiency of heat utilization, whose values have been set at 1,0 [8]. The volume of each efficiency adopted on the basis of tables 9, 12 and 14 of the Regulation [8] are summarized in Table 2 .

Table 2. Summary of the efficiency of systems which supply hot water.

\begin{tabular}{|c|c|c|c|c|c|}
\hline Variant & Energy carrier & $\begin{array}{c}\text { Efficiency of } \\
\text { the heat } \\
\text { production }\end{array}$ & $\begin{array}{c}\text { Efficiency of } \\
\text { the heat } \\
\text { transfer }\end{array}$ & $\begin{array}{c}\text { Efficiency of } \\
\text { the heat } \\
\text { accumulation }\end{array}$ & $\begin{array}{c}\text { Total system } \\
\text { efficiency }\end{array}$ \\
\hline 1 & Electric energy & 0.96 & & 1.00 & 0.67 \\
\cline { 1 - 3 } 2 & Coal & 0.83 & & & 0.49 \\
\hline 3 & Beech wood & 0.83 & \multirow{2}{*}{0.70} & \multirow{2}{*}{0.85} & 0.49 \\
\hline 4 & Natural gas & 0.85 & & & 0.51 \\
\hline 5 & Heating oil & 0.85 & & & 0.51 \\
\hline 6 & Electric energy & 2.60 & & & 1.55 \\
\hline
\end{tabular}

The efficiency of the system is a parameter of fundamental importance as it directly affects the amount of energy used to produce hot water. The highest efficiency is observed in the system with a heat pump which uses a renewable source of heat. While taking into 
account the conventional systems, the highest efficiency is noted in the an electric heater installation. In this case, not only is the efficiency of the equipment high, but also the efficiency of accumulation, due to the absence of additional equipment installed in the hot water tank. The higher the efficiency of the system of supplying the building in hot water, the lower the operating costs are, borne by an investor and the installation is more economical.

The calculative, annual amount of electricity required in the system for preparation of hot, tap water is calculated by the formula (2) and in other energy sources, the formula (3) $[8]$ is used.

$$
\begin{gathered}
C_{W}=Q_{k, W} / A_{f}\left[\mathrm{kWh} /\left(\mathrm{m}^{2} \cdot \text { year }\right)\right] \\
C_{W}=\frac{Q_{k, W} \cdot 3,6}{A_{f} \cdot W_{o}}\left[\text { reference unit } /\left(\mathrm{m}^{2} \cdot \text { year }\right)\right]
\end{gathered}
$$

where:

$Q_{k, W}$ - annual demand for an end use energy delivered to the building system for the preparation of hot water [kWh/year)],

$A_{f}$ - heated floor space $\left[\mathrm{m}^{2}\right]$,

$W_{o}$ - calorific value of the fuel $[\mathrm{MJ} /$ reference unit $]$.

The total annual amount of fuel is calculated using the formula (4), then the results are given in Table 3.

$$
R=C_{W} \cdot A_{f}[\text { reference unit } /(\text { year })]
$$

Table 3. Summary of the total annual amount of fuel depending on building types.

\begin{tabular}{|l|c|c|c|c|c|c|}
\hline \multirow{2}{*}{ Type of building } & \multicolumn{7}{|c|}{ The total annual amount of fuel } \\
\cline { 2 - 7 } & $\begin{array}{c}\text { Variant 1 } \\
\text { [kWh/year] }\end{array}$ & $\begin{array}{c}\text { Variant 2 } \\
\text { [kg/ year] }\end{array}$ & $\begin{array}{c}\text { Variant 3 } \\
\text { [kg/ year] }\end{array}$ & $\begin{array}{c}\text { Variant 4 } \\
{\left[\mathbf{m}^{3} / \text { year] }\right.}\end{array}$ & $\begin{array}{c}\text { Variant 5 } \\
{[\mathbf{l} / \text { year] }}\end{array}$ & $\begin{array}{c}\text { Variant 6 } \\
\text { [kWh/ year] }\end{array}$ \\
\hline Office building & 11152 & 1971 & 3545 & 1486 & 1470 & 4844 \\
\hline $\begin{array}{l}\text { Apartment } \\
\text { building }\end{array}$ & 65544 & 11583 & 20838 & 8735 & 8640 & 28471 \\
\hline Restaurant & 91033 & 16087 & 28942 & 12132 & 12000 & 39544 \\
\hline Shopping centre & 21302 & 3764 & 6772 & 2839 & 2808 & 9253 \\
\hline Hotel & 102412 & 18098 & 32560 & 13649 & 13500 & 44487 \\
\hline Warehouse & 3186 & 563 & 1013 & 425 & 420 & 1384 \\
\hline School & 20027 & 3539 & 6367 & 2669 & 2640 & 8700 \\
\hline Hospital & 295865 & 52284 & 94061 & 39429 & 38999 & 128517 \\
\hline Sports hall & 4722 & 835 & 1501 & 629 & 623 & 2051 \\
\hline
\end{tabular}

Estimated annual operating costs, which, excluding the price of the energy source, consist of the cost of the operation of auxiliary equipment, including circulating pumps and the hot water tank charging pumps. Demand for end use energy for the drive of the pumps for the analysed systems for the preparation the hot water is equal to $653 \mathrm{kWh} / \mathrm{year}$, which amounts to 87 EUR annually. Only in the case of the system with an electric heater, the 
value is lower, since there is no need to mount a charging pump on the tank, a fixed demand for end use electric energy is equal to $467 \mathrm{kWh} /$ year, which is 62,3 EUR annually. The unit cost of heat for specific fuels are assumed on the basis of available data from the utilities suppliers or their price lists, and they are summarized in Table 4. The results of the calculation of annual operating costs are presented in Table 5.

Table 4. The unit cost of heat for specific fuels.

\begin{tabular}{|c|c|c|c|c|c|}
\hline Type of fuel & Electric energy & Coal & Beech wood & Natural gas & Heating oil \\
\hline Price & $0,13 \mathrm{EUR} / \mathrm{kWh}$ & $216 \mathrm{EUR} / \mathrm{t}$ & $60,8 \mathrm{EUR} / \mathrm{m}^{3}$ & $0,47 \mathrm{EUR} / \mathrm{m}^{3}$ & $0,66 \mathrm{EUR} / 1$ \\
\hline
\end{tabular}

Table 5. Annual operating costs.

\begin{tabular}{|l|c|c|c|c|c|c|}
\hline \multirow{2}{*}{ Type of building } & \multicolumn{7}{|c|}{ Annual operating costs [EUR/year] } \\
\cline { 2 - 7 } & Variant 1 & Variant 2 & Variant 3 & Variant 4 & Variant 5 & Variant 6 \\
\hline Office building & 1549 & 513 & 617 & 787 & 1050 & 733 \\
\hline Apartment building & 8801 & 2590 & 3201 & 4204 & 5748 & 3883 \\
\hline Restaurant & 12200 & 3563 & 4412 & 5804 & 7949 & 5360 \\
\hline Shopping centre & 2903 & 900 & 1099 & 1425 & 1927 & 1321 \\
\hline Hotel & 13717 & 3998 & 4952 & 6519 & 8932 & 6019 \\
\hline Warehouse & 487 & 209 & 238 & 287 & 362 & 272 \\
\hline School & 2733 & 852 & 1038 & 1345 & 1817 & 1247 \\
\hline Hospital & 39511 & 11385 & 14142 & 18669 & 25638 & 17223 \\
\hline Sports hall & 692 & 267 & 311 & 384 & 495 & 361 \\
\hline
\end{tabular}

The calculated indicators for the amount of energy necessary to heat a unit volume of hot water to a desired temperature depending on the type of fuel and the purpose of the building. They are summarized in Table 6 .

The determined indicators of production costs per unit volume of hot water of the analysed hot water preparation systems and building types are given in Table 7 and graphically in Figure 1.

Table 8 summarizes the average levels of energy required and the cost of production per unit volume of hot water depending on the heat source.

Analyzing the results of the calculations presented in the article, it is noticeable that the preparation cost of domestic hot, tap water is affected not only by the type of energy source, but also by the function of the premises. 
Table 6. Indicators for the amount of energy necessary to heat a unit volume of hot water.

\begin{tabular}{|c|c|c|c|c|c|c|}
\hline \multirow{2}{*}{ Type of building } & \multicolumn{6}{|c|}{$\begin{array}{l}\text { The indicator of the amount of fuel needed to heat a unit volume of } \\
\text { hot water }\end{array}$} \\
\hline & $\begin{array}{l}\text { Variant } 1 \\
{\left[\mathbf{k W h} / \mathbf{m}^{3}\right]}\end{array}$ & $\begin{array}{l}\text { Variant } 2 \\
{\left[\mathrm{~kg} / \mathrm{m}^{3}\right]}\end{array}$ & $\begin{array}{l}\text { Variant } 3 \\
{\left[\mathrm{~kg} / \mathrm{m}^{3}\right]}\end{array}$ & $\begin{array}{l}\text { Variant } 4 \\
{\left[\mathrm{~m}^{3} / \mathbf{m}^{3}\right]}\end{array}$ & $\begin{array}{l}\text { Variant } 5 \\
{\left[1 / \mathbf{m}^{3}\right]}\end{array}$ & $\begin{array}{l}\text { Variant } 6 \\
{\left[\mathbf{k W h} / \mathbf{m}^{3}\right]}\end{array}$ \\
\hline Office building & 19.91 & 3.52 & 6.33 & 2.65 & 2.62 & 8.65 \\
\hline Apartment building & 25.60 & 4.52 & 8.14 & 3.41 & 3.37 & 11.12 \\
\hline Restaurant & 22.76 & 4.02 & 7.24 & 3.03 & 3.00 & 9.89 \\
\hline Shopping centre & 22.19 & 3.92 & 7.05 & 2.96 & 2.92 & 9.64 \\
\hline Hotel & 17.07 & 3.02 & 5.43 & 2.27 & 2.25 & 7.41 \\
\hline Warehouse & 19.91 & 3.52 & 6.33 & 2.65 & 2.62 & 8.65 \\
\hline School & 15.65 & 2.76 & 4.97 & 2.09 & 2.06 & 6.80 \\
\hline Hospital & 28.45 & 5.03 & 9.04 & 3.79 & 3.75 & 12.36 \\
\hline Sports hall & 11.81 & 2.09 & 3.75 & 1.57 & 1.56 & 5.13 \\
\hline
\end{tabular}

Table 7. Indicators of production costs per unit volume of hot water.

\begin{tabular}{|c|c|c|c|c|c|c|}
\hline \multirow{2}{*}{ Type of building } & \multicolumn{6}{|c|}{ Indicators of production costs per unit volume of hot water $\left[\mathrm{EUR} / \mathrm{m}^{3}\right]$} \\
\hline & Variant 1 & Variant 2 & Variant 3 & Variant 4 & Variant 5 & Variant 6 \\
\hline Office building & 2.77 & 0.92 & 1.10 & 1.41 & 1.88 & 1.31 \\
\hline Apartment building & 3.44 & 1.01 & 1.25 & 1.64 & 2.25 & 1.52 \\
\hline Restaurant & 3.05 & 0.89 & 1.10 & 1.45 & 1.99 & 1.34 \\
\hline Shopping centre & 3.02 & 0.94 & 1.14 & 1.48 & 2.01 & 1.38 \\
\hline Hotel & 2.29 & 0.67 & 0.83 & 1.09 & 1.49 & 1.00 \\
\hline Warehouse & 3.04 & 1.30 & 1.49 & 1.79 & 2.26 & 1.70 \\
\hline School & 2.13 & 0.67 & 0.81 & 1.05 & 1.42 & 0.97 \\
\hline Hospital & 3.80 & 1.09 & 1.36 & 1.80 & 2.47 & 1.66 \\
\hline Sports hall & 1.73 & 0.67 & 0.78 & 0.96 & 1.24 & 0.90 \\
\hline
\end{tabular}




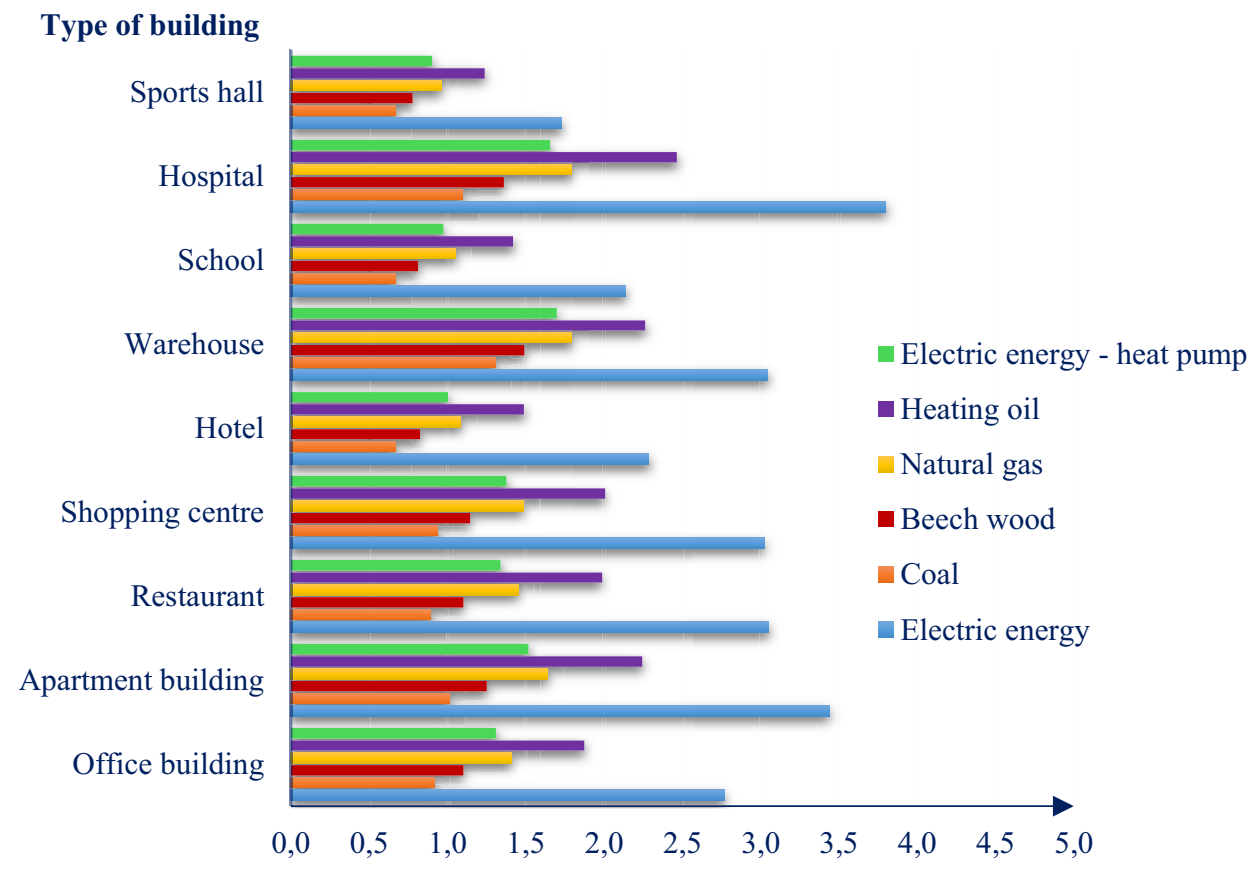

Indicators of production costs per unit of hot water $\left[\mathrm{EUR} / \mathrm{m}^{3}\right]$

Fig. 1. Indicators of production costs per unit of hot water depending on the type of heat source and destination of a building.

Table 8. Average levels of energy required and the cost of production per unit volume of hot water.

\begin{tabular}{|c|c|c|c|c|c|}
\hline \multicolumn{6}{|c|}{ Average levels of energy required to production unit volume of hot water } \\
\hline $\begin{array}{c}\text { Electric energy } \\
{\left[\mathrm{kWh} / \mathrm{m}^{3}\right]}\end{array}$ & $\begin{array}{c}\mathrm{Coal} \\
{\left[\mathrm{kg} / \mathrm{m}^{3}\right]}\end{array}$ & $\begin{array}{l}\text { Beech wood } \\
{\left[\mathrm{kg} / \mathrm{m}^{3}\right]}\end{array}$ & $\begin{array}{c}\text { Natural gas } \\
{\left[\mathrm{m}^{3} / \mathrm{m}^{3}\right]}\end{array}$ & $\begin{array}{l}\text { Heating oil } \\
{\left[1 / \mathrm{m}^{3}\right]}\end{array}$ & $\begin{array}{c}\text { Electric energy - heat pump } \\
{\left[\mathrm{kWh} / \mathrm{m}^{3}\right]}\end{array}$ \\
\hline 20,37 & 3.60 & 6.48 & 2.71 & 2.69 & 8.85 \\
\hline \multicolumn{6}{|c|}{ Average levels of the cost of production per unit volume of hot water $\left[\mathrm{EUR} / \mathrm{m}^{3}\right]$} \\
\hline Electric energy & Coal & Beech wood & Natural gas & Heating oil & Electric energy - heat pump \\
\hline 2,81 & 0.91 & 1.10 & 1.41 & 1.89 & 1.31 \\
\hline
\end{tabular}

The cheapest source of heat is a coal-fired boiler, hence its popularity is at a high level, especially in households. This solution does not seem to be optimal, given the user's comfort and the impact on the natural environment. In terms of the economical aspect of a system for the supply of hot water supply, are in second and third place respectively: a biomass boiler (beech wood) and a heat pump (air/water). It turns out that investment in alternative energy sources is not always the most cost-effective option [10]. In the case of heat pumps, it is due to the fact that the transfer of "free" energy from the heat source to the installation involves the consumption of electricity. Clearly, the more expensive source of heat, from the rest, is a boiler using heating oil. The most expensive option is the electric heater. 
Due to the characteristics of water partitioning, as well as the specifics of the building, the greatest amount of energy is required for the preparation of hot water in a hospital, and the least in a sports hall.

\section{Summary}

The selection of the right energy source, which powers the hot, tap water supply system in a building is one of the most important decisions to make for an investor, especially if it relates to large facilities where water consumption is significant. Besides the comfort of the user, or sanitary security, the fundamental role is played by the economical criterion.

A comparative analysis of systems for the preparation of hot, tap water, carried out in the article, showed that the cost of production of one cubic meter of hot water ranges from 0,67 EUR to as much as 3,80 EUR, depending on the energy source and the function of the premises. The cheapest source of heat is a coal-fired boiler, and the most expensive is a capacitive electric heater. For some types of buildings, e.g. a school or a hotel, it is more than three times more expensive than a coal boiler, and more than two times more expensive in comparison with a heat pump.

Every investment must be considered individually, and the selection of a suitable system for hot, tap water should be based on multi-criteria analysis. The indicators of the amount of energy and production costs of the hot water, set out in the article, provide information which is helpful in making the right choice.

\section{References}

1. S. Kordana, D.Słyś, JCEEA, XXXIII, 63 (2/II/16), 225-240 (2016)

2. D.Słyś, S. Kordana, ENERG BUILDINGS, 71, 1-11 (2014)

3. A. Stec, S. Kordana, RESOUR CONSERV RECY, 105, 84-94 (2015)

4. C. Naldi, M. Dongellini, G. L. Morini, Energy Procedia, 78, 1117-1122 (2015)

5. X. Sun, Y. Dai, V. Novakovic, J. Wu, R. Wang, Energy Procedia, 70, 394-401 (2015)

6. G. Comodi, M. Bevilacqua, F. Caresana, C. Paciarotti, L.Pelagalli, P.Venella, APPL ENERG, 164, 944-955 (2016)

7. T. Szul, Journal of Research and Applications in Agricultural Engineering, 56(2), 161-164 (2011)

8. Journal of Laws of 2015, item 376, Rozporządzenie Ministra Infrastruktury i Rozwoju z dnia 27 lutego 2015 r. $w$ sprawie metodologii wyznaczania charakterystyki energetycznej budynku lub czesści budynku oraz świadectw charakterystyki energetycznej (Regulation of the Minister of Infrastructure and Development of 27 February 2015 on the methodology for determining the energy performance of a building or part of a building and energy performance certificates)

9. Journal of Laws of 2002, No. 75, item 690, as amended, Rozporządzenie Ministra Infrastruktury z dnia 12 kwietnia 2002 r. w sprawie warunków technicznych, jakim powinny odpowiadać budynki $i$ ich usytuowanie (Regulation of the Minister of Infrastructure of 12 April 2002 on technical specifications that buildings and their location should comply with)

10. T. Szul, Journal of Research and Applications in Agricultural Engineering, 58(2), 158-162 (2013) 